\title{
Endoscopic Transsphenoidal Surgery for Cushing's Disease: A Review
}

\author{
Mirza Zain Baig ${ }^{1}$, Altaf Ali Laghari ${ }^{2}$, Aneela Darbar ${ }^{3}$, Umm E Hani Abdullah ${ }^{3}$, Sumiya Abbasi ${ }^{4}$ \\ 1. Surgical Oncology, Rudy L. Ruggles Biomedical Research Institute, Danbury, USA 2. Neurosurgery, Aga Khan \\ University Hosiptal, Karachi, PAK 3. Neurosurgery, Aga Khan University Hospital, Karachi, PAK 4. Epidemiology, \\ Liaquat College of Medicine \& Dentistry, Karachi, PAK
}

Corresponding author: Altaf Ali Laghari, altaf.alilaghari@aku.edu

\begin{abstract}
Ever since the 1960s, transsphenoidal surgery has been the modality of choice for treating Cushing's disease. Subsequent visualization of the pituitary fossa and sphenoid sinus may be done either with the operating microscope or with the relatively new endoscope. The endoscope due to its panoramic view allows greater visualization as compared to the operating microscope. It confers greater access to the cavernous sinus, sella, suprasellar, and parasellar regions and accommodates higher magnifications. It is bi-dimensional, however as opposed to the operating microscope that provides a three-dimensional view and allows greater depth perception. This article provides a comprehensive review of the advantages and disadvantages of the endoscope and compares it to the operating microscope. We hope this article will prove useful to both clinicians and academicians alike in their approach and management of Cushing's disease.
\end{abstract}

Categories: Neurosurgery

Keywords: cushing disease, endoscopic endonasal, trans-sphenoidal surgery, operating microscope

\section{Introduction And Background}

Cushing syndrome is defined as a state of prolonged hypercortisolism and its accompanying manifestations. When attributable to a pituitary origin, typically a pituitary adenoma or rarely a carcinoma, it is known as Cushing's disease - named after and first described by Dr. Harvey Cushing in 1932 [1-4].

Cushing's disease is the most common cause of endogenous hypercortisolism [4-8]. It is a rare disorder that has an incidence of 1.2 to 2.4 cases/million/ year [9-10]. Its estimated prevalence is nearly 40 cases per million [9]. It is associated with considerable morbidity and mortality [3]. Five-year mortality rates are estimated to be $50 \%[3,10]$. Its presenting features and long-term complications include rapidly increasing weight, truncal obesity, abdominal striations, moon facies, buffalo hump, proximal myopathy, hypertension, easy bruising, depression, reduced immunity and metabolic disturbances such as metabolic syndrome, diabetes mellitus, deranged lipid profiles, and osteoporosis [3-4,6,8,10-13].

Received 05/12/2019

Review began 06/21/2019 Review ended 07/20/2019 Published 07/27/2019

\section{() Copyright 2019}

Baig et al. This is an open access article distributed under the terms of the Creative Commons Attribution License CC-BY 3.0., which permits unrestricted use, distribution, and reproduction in any medium, provided the original author and source are credited.
The first report on the transsphenoidal route to access the pituitary dates back to 1907 by Hermann Schloffer, after which further attempts at exploration were abandoned for nearly half a century [14-15]. It was during the 1960s that the transsphenoidal approach gained popularity and became the established treatment of choice for patients with Cushing's disease [7-8,15-26]. This was due to the introduction of the operating microscope by Jules Hardy [14]. High remission rates coupled with few complications have encouraged the widespread use of the transsphenoidal route [8,16,20]. Only exceptionally, a transcranial approach may be needed [27]. In the 1990s, Jho pioneered an endoscopic transnasal technique that has become an alternative to the microscopic technique [14].

This article aims to compare the two techniques by summarizing the findings of recent clinical series published in literature with a special focus on the advantages of the endoscope along with any shortcomings when compared to the operating microscope. We hope this article will prove useful to clinicians and academicians alike in their approach and management of Cushing's disease.

\section{Review}

Traditionally the transseptal/translabial approach with the use of the operating microscope is the gold standard transsphenoidal approach $[8,15,17,20,24]$. It is associated with minimal morbidity and mortality [15]. However, with recent advances, the endoscope has come forward as an effective tool - one with the potential to perhaps surpassing the use of the microscope to become the modality of choice in Cushing's disease [15,20-21,28-32]. Many studies throughout the literature comment on the endoscope's ability to achieve better resection rates, lesser invasiveness, and fewer complications [7,17,20-22]. Advocates of the microscope, however, criticize its panoramic view for its lack of three-dimensional vision and depth perception, and the inability to conduct meticulous microsurgical procedures that comes with it $[7,19,21]$. Others, meanwhile favor the panoramic view as it leads to better visualization of the bony structures 
Remission rates, reported in the literature for transsphenoidal surgery for Cushing's disease vary between $42 \%$ and $95 \%$ [21]. The majority of remission rates lie between $70 \%$ and $85 \%$ with no significant improvement in the past years [21]. According to Qiao et al, there is no difference in remission rates between the endoscope and the microscope for Cushing's disease [30]. There may be fewer recurrences with the endoscope but this advantage disappears when follow up time is taken into account [30].

Being a relatively newer innovation, there are only a few reports that look at the efficiency and prognostics of a purely endoscopic technique for Cushing's disease. The effectiveness of pituitary surgery is evaluated by normalization of hormone levels and degree of tumor removal [15]. At the moment, data suggests that the endoscope is at least equivalent or in some cases even superior to the operating microscope [15,22]. Please refer to Table 1 for the salient features including remission rates, recurrences, complications, etc. of clinical series published in the literature on the use of the endoscope for Cushing's disease [2,7-9,17-

$18,21,26,29,32,34]$

\begin{tabular}{|c|c|c|c|c|}
\hline Paper & $\begin{array}{l}\text { Patient } \\
\text { characteristics }\end{array}$ & Modality & Findings & Complications \\
\hline $\begin{array}{l}\text { Natea -Maier } \\
\text { et al, } 2006[7]\end{array}$ & $\begin{array}{l}35 \text { patients }(25 \\
\text { females and } 10 \\
\text { males). Mean } \\
\text { age of } 41.0 \\
\pm 14.8\end{array}$ & Endoscope & $\begin{array}{l}\text { The remission rate of } 77 \% \text { after the } \\
\text { first surgery and } 83 \% \text { after re- } \\
\text { operation. The recurrence rate was } \\
22.8 \% \text {. }\end{array}$ & $\begin{array}{l}48 \% \text { of the patients developed } \\
\text { hypopituitarism. Severe epistaxis in one } \\
\text { patient. } 3 \text { patients developed CSF } \\
\text { leakage. } 3 \text { patients had polyuria, and } 1 \\
\text { developed hyponatremia. } 1 \text { developed } \\
\text { mild hyponatremia. }\end{array}$ \\
\hline $\begin{array}{l}\text { Dehdashti et } \\
\text { al, } 2007 \text { [21] }\end{array}$ & $\begin{array}{l}25 \text { patients }(19 \\
\text { females and } 6 \\
\text { males). Mean } \\
\text { age of } 42 \pm 2.5\end{array}$ & Endoscope & $\begin{array}{l}\text { The remission rate was } 83 \% \text {. None of } \\
\text { the patients presented with recurrence } \\
\text { at a median follow up of } 17 \text { months. }\end{array}$ & $\begin{array}{l}1 \text { patient had a postoperative CSF leak. } 1 \\
\text { patient developed transitory DI. }\end{array}$ \\
\hline $\begin{array}{l}\text { Starke et al, } \\
2012[34]\end{array}$ & $\begin{array}{l}61 \text { patients }(52 \\
\text { females and } 9 \\
\text { males). Mean } \\
\text { age of } 49 \text { (14- } \\
63 \text { ) }\end{array}$ & Endoscope & $\begin{array}{l}\text { The immediate remission rate of } 95 \% \text {. } \\
\text { The remission rate of } 84 \% \text { in patients } \\
\text { with at least one year follow up. With } \\
\text { additional adjuvant therapy, } 94 \% \\
\text { successfully achieved remission. No } \\
\text { significant difference in remission rates } \\
\text { between microadenomas (93\%), } \\
\text { macroadenomas ( } 77 \% \text { ) and MRI- } \\
\text { negative Cushing's (100\%). }\end{array}$ & $\begin{array}{l}1 \text { patient had a postoperative CSF leak. } 1 \\
\text { patient presented with severe epistaxis. }\end{array}$ \\
\hline $\begin{array}{l}\text { Smith et al, } \\
2012 \text { [32] }\end{array}$ & $\begin{array}{l}72 \text { patients- } \\
\text { male to female } \\
\text { ratio was } 1: 3.7 . \\
\text { The median } \\
\text { age of } 40 \text { years } \\
(31-50) .\end{array}$ & $\begin{array}{l}\text { Operating } \\
\text { microscope- } \\
58 \text { patients } \\
\text { Endoscope- } \\
14 \text { patients }\end{array}$ & $\begin{array}{l}\text { The initial remission rate was } 72 \% \text {. } \\
\text { The recurrence rate was } 11 \% \text {. The } \\
\text { median time of recurrence after initial } \\
\text { remission was } 2.1 \text { years. No significant } \\
\text { difference between the operating } \\
\text { microscope and endoscope. }\end{array}$ & $\begin{array}{l}3 \text { patients developed meningitis. } 1 \text { patient } \\
\text { developed sinusitis postoperatively. } 1 \\
\text { patient had a septal perforation. } 1 \text { patient } \\
\text { had a blocked lacrimal duct. Common } \\
\text { complications seen were transient DI and } \\
\text { postoperative CSF leak. }\end{array}$ \\
\hline $\begin{array}{l}\text { Wagenmakers } \\
\text { et al, } 2013 \\
\text { [29] }\end{array}$ & $\begin{array}{l}86 \text { patients }(72 \\
\text { women and } 14 \\
\text { men). Mean } \\
\text { age } 42.3 \pm 14.9\end{array}$ & Endoscope & $\begin{array}{l}\text { Remission rate } 60 \% \text { in MRI-negative } \\
\text { Cushing's disease, } 83 \% \text { in } \\
\text { microadenomas, } 94 \% \text { in noninvasive } \\
\text { macroadenomas, and } 40 \% \text { in } \\
\text { macroadenomas invading the } \\
\text { cavernous sinus. The recurrence rate } \\
\text { was } 16 \% \text { after } 71+39 \text { months of follow- } \\
\text { up. }\end{array}$ & $\begin{array}{l}\text { Postoperative bleeding from the } \\
\text { sphenopalatine artery in } 1 \text { patient. } \\
\text { Pulmonary embolism in } 1 \text { patient of } \\
\text { persistent Cushing's disease after surgery. } \\
\text { Postoperative CSF leak in } 4 \text { patients. } \\
\text { Transient DI in } 4 \text { patients. Transient } \\
\text { hyponatremia due to inappropriate ADH } \\
\text { secretion or relative glucocorticoid } \\
\text { deficiency in } 10 \text { patients. Infection in } 3 \\
\text { patients. }\end{array}$ \\
\hline $\begin{array}{l}\text { Berker et al, } \\
2013[8]\end{array}$ & $\begin{array}{l}90 \text { patients }(79 \\
\text { women and } 11 \\
\text { men). Mean } \\
\text { age } 38.74 \pm \\
13.01\end{array}$ & Endoscope & $\begin{array}{l}\text { Remission achieved in } 90 \% \text { of } \\
\text { patients }(86.9 \% \text { microadenomas, } \\
96.6 \% \text { macroadenomas, } 95.7 \% \\
\text { primary patients, } 71.4 \% \text { recurrent/ } \\
\text { persistent disease. The recurrence rate } \\
\text { was } 5.6 \% \text {. Reentered remission after } \\
\text { reoperation }\end{array}$ & $\begin{array}{l}\text { Intraoperative CSF leak in } 8 \text { patients. Out } \\
\text { of which, } 2 \text { had a postoperative leak as } \\
\text { well. Temporary DI in } 7 \text { patients } \\
\text { Permanent DI in } 1 \text { patient. Postoperative } \\
\text { meningitis after two weeks in } 1 \text { patient. }\end{array}$ \\
\hline
\end{tabular}




\section{Cureus}

\begin{tabular}{|c|c|c|c|c|}
\hline $\begin{array}{l}\text { Storr et al } \\
2014 \text { [17] }\end{array}$ & $\begin{array}{l}\text { Six pediatric } \\
\text { patients ( } 5 \\
\text { males and } 1 \\
\text { female). Mean } \\
\text { age } 14.6\end{array}$ & Endoscope & $\begin{array}{l}\text { Remission achieved in } 83.3 \% \text { of the } \\
\text { patients. No recurrence at mean } 4.7 \\
\text { years follow up }\end{array}$ & $\begin{array}{l}\text { Intraoperative sinus bleeds in } 1 \text { patient. } \\
\text { Postoperative CSF leak in } 1 \text { patient. } \\
\text { Panhypopituitarism in } 1 \text { patient. GH and } \\
\text { gonadotropin deficiency in } 1 \text { patient. }\end{array}$ \\
\hline $\begin{array}{l}\text { Kuo et al, } \\
2015 \text { [26] }\end{array}$ & $\begin{array}{l}40 \text { patients ( } 38 \\
\text { females and } 2 \\
\text { males). Mean } \\
\text { age } 41 \pm 13\end{array}$ & & $\begin{array}{l}\text { Remission achieved in } 72.5 \%(81.8 \% \\
\text { microadenomas, } 77.8 \% \text { noninvasive } \\
\text { macroadenomas, } 44.4 \% \\
\text { macroadenomas that invaded the } \\
\text { cavernous sinus. Recurrent/ persistent } \\
\text { disease in } 11 \text { patients }\end{array}$ & CSF leak in 5 patients. \\
\hline $\begin{array}{l}\text { Sarkar et al, } \\
2016 \text { [18] }\end{array}$ & $\begin{array}{l}64 \text { patients } \\
\text { Mean age } 31.9 \\
\pm 9.6\end{array}$ & Endoscope & $\begin{array}{l}\text { Remission in } 79.7 \% \text { of the } 59 \text { cases } \\
\text { followed up for }>3 \text { months and was } \\
\text { superior for microadenomas }(86.4 \%) \\
\text { versus macroadenomas ( } 55.6 \%) \text { and } \\
\text { equivocal MRI adenomas }(66.7 \%) \text {. }\end{array}$ & $\begin{array}{l}\text { Postoperative CSF rhinorrhea occurred in } \\
5 \text { patients. New endocrine deficits in } 17.1 \\
\% \text { of patients. }\end{array}$ \\
\hline $\begin{array}{l}\text { Cebula et al, } \\
2017 \text { [2] }\end{array}$ & $\begin{array}{l}230 \text { patients. } \\
\text { Mean age of } \\
42 \pm 13.5 \text { years }\end{array}$ & Endoscope & $\begin{array}{l}\text { Remission in } 79.1 \% \text { of patients after a } \\
\text { median follow up of } 21 \pm 19.2 \text { months. } \\
\text { The remission rate was significantly } \\
\text { increased for microadenomas and } \\
\text { positive histology. The recurrence rate } \\
\text { of } 9.8 \% \text { with a mean time } 32.7 \pm 15.2 \\
\text { months. }\end{array}$ & $\begin{array}{l}\text { Post-operative complication occurred in } \\
77 \text { patients ( } 35.5 \%) \text {. Predominant } \\
\text { postoperative complications were } \\
\text { transient DI and intraoperative CSF } \\
\text { leakage ( } 22 \% \text { and } 12.6 \% \text { respectively). } \\
\text { The rate of long-term DI was } 6.4 \% \text {. Two } \\
\text { cases of transient visual complications } \\
\text { occurred. Four people had epistaxis. }\end{array}$ \\
\hline $\begin{array}{l}\text { Donofrio et al, } \\
2017 \text { [9] }\end{array}$ & $\begin{array}{l}709 \text { patients } \\
\text { (142 Cushing's } \\
\text { disease } \\
\text { patients and } \\
299 \\
\text { nonfunctioning } \\
\text { pituitary } \\
\text { adenomas). }\end{array}$ & $\begin{array}{l}\text { Operating } \\
\text { microscope }\end{array}$ & A remission rate of $80.3 \%$. & $\begin{array}{l}\text { Major complications reported in } 7 \\
\text { Cushing's disease patients ( } 4.9 \%) \text {. Minor } \\
\text { complications reported in } 3 \text { Cushing's } \\
\text { disease patients }(2.1 \%) \text {. Postoperative DI } \\
\text { reported was } 10.6 \% \text { and isolated } \\
\text { hyponatremia reported was } 10.6 \% \text {. }\end{array}$ \\
\hline
\end{tabular}

TABLE 1: Summary of case series published on endoscopic transsphenoidal resection of Cushing's disease that were available on PUBMED as full-text articles

Abbreviations: MRI: magnetic resonance imaging, CSF: cerebrospinal fluid, DI: diabetes insipidus, ADH: antidiuretic hormone, GH: growth hormone

\section{Operative technique}

The procedure is done under general anesthesia. It is conducted in collaboration with an otolaryngologist. The patient is kept supine with the head maintained in a fixed position using a three-pin Mayfield clamp. The head of the bed is elevated. Frameless stereotaxy is used for neuronavigation (Figure 1). 


\section{Cureus}
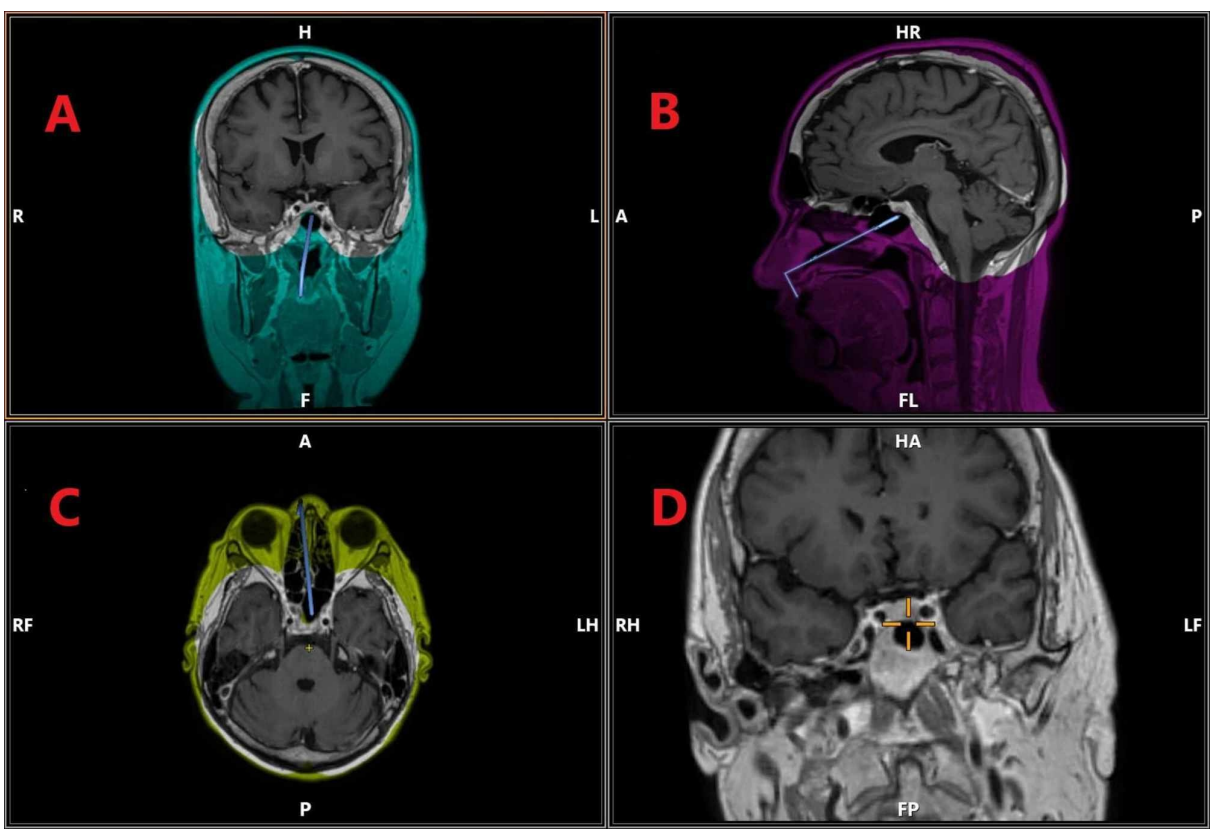

FIGURE 1: Neuronavigational planning of endoscopic transsphenoidal surgery in a patient with Cushing's disease.

(A) T1 with contrast, coronal section. (B) T1 with contrast, saggital section. (C) T1 with contrast, axial section. (D) Magnified coronal section showing a tumor in sellar region, more on the right side

The different color schemes in the figure hold no significance and are a result of the software used for neuronavigational planning

Using the binostril, bimanual technique, the endoscope is inserted and the Hadad flap is raised. The sphenoid ostium is identified. The posterior septum is removed to expose the vomer. The sphenoid sinus is identified and the intersinus septum is removed. The anterior part of the sella is then opened using a drill and Kerrison rongeur.

After identifying the bony landmarks of the optic nerve, carotid artery, and opticocarotid recess, a disc dissector is used to remove dura from the bone of sella floor. The dura is opened and separated from the gland underneath using a micro dissector. Care should be taken not to coagulate dura as this may lead to white discoloration that may hinder tumor identification [19]. Once the bone has been removed, neuronavigation is used to locate the tumor. Resection is then carried out using a micro dissector, suction device, and ring curettes of varying diameters and orientations. The tumor is identified as a discolored gray region upon the orange-pink coloration of the gland.

The sellar defect is repaired using the Hadad flap followed by fibrin adhesive, Surgicell, and Gellfoam.

Video 1 reviews the operative technique for endoscopic transsphenoidal surgery.

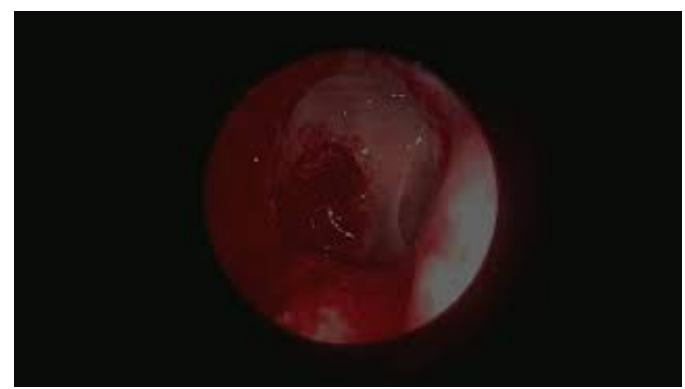

VIDEO 1: Endoscopic transsphenoidal removal of Cushing's disease. Procedure done by authors AAL and AD. Commentary by author MZB.

Abbreviations: AAL: Altaf Ali Laghari, AD: Aneela Darbar, MZB: Mirza Zain Baig 


\section{Cureus}

In cases of negative magnetic resonance imaging (MRI), inferior petrosal sinus sampling (IPSS) is done to determine the lateralization of the disease. A selective adenectomy is done in cases where the tumor is identified on surgical exploration. Otherwise, subtotal hypophysectomy is done on the side of IPSS lateralization. Refer to Figure 2 for a summary of the workup done for Cushing’s syndrome.

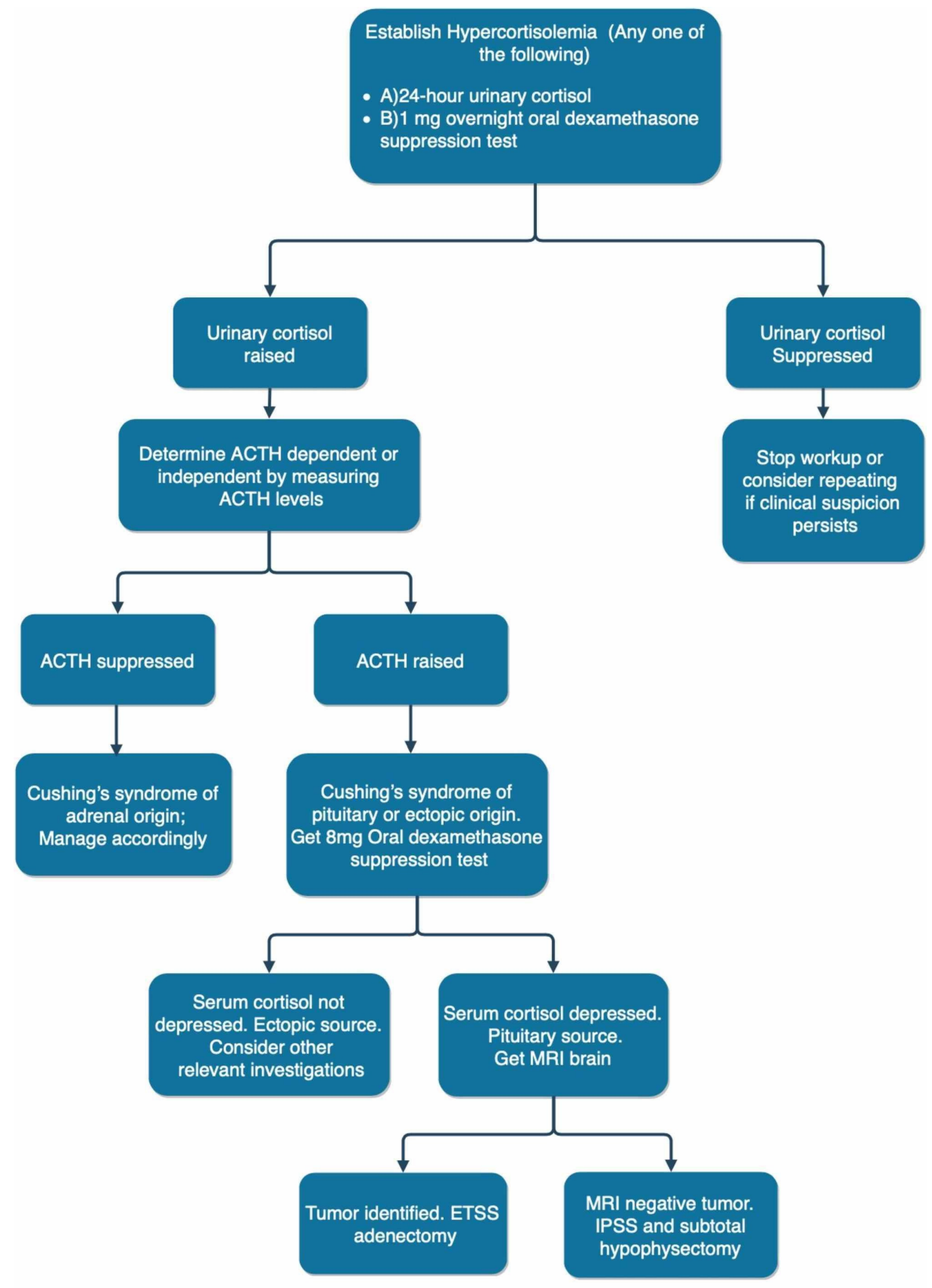

\section{FIGURE 2: Diagnostic workup of Cushing's syndrome}

Abbreviations: ACTH: adrenocorticotropic hormone; MRI: magnetic resonance imaging; ETSS: endoscopic transsphenoidal surgery; IPSS: inferior petrosal sinus sampling

\section{Advantages of the endoscope}

The hallmark feature of endoscopic transsphenoidal surgery is the superior view one has of the sphenoid sinus and the pituitary fossa $[7-8,13,15,17,20,22,30,34,36]$. It gives greater lighting hence contributing to the better visualization and - depending on the scope used - an ability to operate at an angle $[7-8,13,15,21,30]$. Its panoramic vision allows greater exploration of the sella, suprasellar, and parasellar regions including the 
cavernous sinus area - as opposed to the traditional microscope that allows visualization only in a straight line between the scope and the pathology being observed [7-8,13,15,20-22,30,34]. This means that the surgeon can now visualize tumors superiorly at the base of the third ventricle, inferiorly to the lower clivus, and laterally to the carotids and the cavernous [15]. The endoscope also allows higher magnifications, which make it an excellent choice for patients with Cushing's disease which are typically small tumors.

Another significant advantage of the endoscope is that it allows the surgeon greater access to the cavernous sinus $[30,35]$. Previously tumor invasion of the cavernous sinus was considered a negative prognosticator and an absolute contradiction to surgery [35]. It has been rightfully called the anatomic jewel box by Parkinson due to the density of neurovascular structures within its dural walls [25]. With the development of the endoscope, however, this is no longer the case and tumors reaching into the cavernous sinus can be successfully operated on and removed using a 30-degree scope [35].

Since the endoscopic approach does not utilize transseptal dissection, there is less post-operative pain and discomfort [7-8,17]. Hospital stays are shorter with fewer complications [7-8,17,22]. In particular, there are decreased incidences of septal perforation, epistaxis, and transient Diabetes Insipidus (DI) with the endoscopic technique $[8,13,22]$. This leads to greater patient satisfaction scores. It is because of these reasons and the fact that it causes minimal skull base trauma that Storr et al [17] emphasize the use of endonasal endoscopic transsphenoidal surgery in pediatric age groups. In their case series, Storr et al. also report fewer PICU admissions and blood transfusions. Also, being minimally invasive, reoperation, when needed, is much simpler as compared to the microscope which unfortunately brings about a greater distortion of normal anatomy [8,22]. Additionally, the wider field of vision of the endoscope serves helpful during reoperation when normal anatomical landmarks have been disrupted [17,19,22].

\section{Disadvantages of the endoscope}

The operating microscope resorts to its three-dimensional vision and depth perception, giving the surgeon the ability to operate in three-dimensional space - a feature that is, unfortunately, missing in the endoscope $[7-8,20,30]$. The endoscope is bidimensional and hence does now provide any depth perception $[7,20-21,30]$. This is by far the biggest disadvantage of the endoscope as the lack of stereoscopic vision makes it difficult to discriminate adenomas from surrounding hypophyseal tissue [13]. Although 3D endoscopes have been developed and are available in the market to address this issue, their widespread adaptation and the subsequent results remain to be seen in future literature [30]. There is also the difficulty of manipulating tools through a narrow corridor [8,21]. However, both these issues can be overcome with surgeon experience $[8,21]$. Using a binostril, bimanual technique may also address this $[8,21]$. The learning curve involved in endoscopic transsphenoidal surgery has been investigated in the series by Chao-Hung et al. where the authors stratified their patients temporally and reported greater recurrences in earlier cases [26]. This corroborates the presence of a learning curve in endoscopic transsphenoidal surgeries that required experience and training to be acquired [13,26].

Concerns have also been raised regarding its lack of maneuverability as surgeons can only manipulate tools with one hand unless a holder is used [7]. The use of an assistant may, however, crowd the operative field [7].

Another disadvantage that has been reported is the increased incidence of extracranial manifestations [20]. These include nasal crusting and synechiae formation [20]. This may be a direct result of the repetitive passage of instruments in the nasal cavity [20]. Postoperative nasal debridement is usually required [20].

There is also increased incidences of vascular complications and post-operative cerebrospinal fluid (CSF) leaks with the endoscope [13]. The increase in vascular complications may be attributed to the fact that the surgeon may attempt more radical tumor excision with the endoscope by virtue of the increased view.

\section{Systemic review and meta-analysis}

In our review of the literature, we found several systemic reviews and metanalysis that compared microscopic and endoscopic surgical techniques and prognostics in a heterogeneous population of patients with various pituitary adenomas $[15,20,22,28]$. We found two studies that were accessible as full-text articles that compared the two surgical techniques in the setting of Cushing's disease only [13,30]. The findings of all these studies are summarized in Table $2[13,15,20,22,28,30]$. 


\section{Cureus}

\begin{tabular}{|c|c|c|}
\hline Paper & $\begin{array}{l}\text { Number of } \\
\text { studies and } \\
\text { patients } \\
\text { assessed }\end{array}$ & Findings \\
\hline $\begin{array}{l}\text { Rotenburg } \\
\text { et al, } 2010 \\
\text { [28]. }\end{array}$ & 11 studies & $\begin{array}{l}\text { Fewer complication rates in endoscopic surgeries. Differences in septal perforations were found to be } \\
\text { insignificant in three studies. Decreased operating times, lumbar drains, immediate postoperative DI, } \\
\text { rhinologic complications, length of hospital stay, and pain in endoscopic approach. Degree of tumor } \\
\text { resection and change in post-operative hormone levels comparable in both techniques. }\end{array}$ \\
\hline $\begin{array}{l}\text { Goudakos } \\
\text { et al, } 2011 \\
\text { [15]. }\end{array}$ & $\begin{array}{l}11 \text { studies } \\
806 \text { patients } \\
(369 \text { had } \\
\text { endoscopic } \\
\text { surgery and } \\
437 \text { had } \\
\text { microscopic } \\
\text { surgery) }\end{array}$ & $\begin{array}{l}66 \% \text { remission rate in the endoscopic group versus } 60 \% \text { in the microscopic group. Degree of tumor } \\
\text { resection comparable in both techniques. No significant difference between the rates of CSF leaks } \\
\text { between the endoscope ( } 19.5 \%) \text { and the microscope }(14.4 \%) \text {. Significantly shorter hospital stays with } \\
\text { the endoscopic technique ( } 3.7-4.4 \text { days) versus microscopic technique }(5.4-5.7 \text { days). }\end{array}$ \\
\hline $\begin{array}{l}\text { Ammirati } \\
\text { et al, } 2012 \\
\text { [20]. }\end{array}$ & $\begin{array}{l}24 \text { cohort } \\
\text { studies } 1670 \\
\text { patients (702 } \\
\text { had } \\
\text { endoscopic } \\
\text { surgery and } \\
968 \text { had } \\
\text { microscopic } \\
\text { surgery) }\end{array}$ & Higher rates of vascular complications with the endoscope \\
\hline $\begin{array}{l}\text { Esquenazi } \\
\text { et al, } 2017 \\
\text { [22]. }\end{array}$ & $\begin{array}{l}21 \text { studies } \\
940 \text { patients } \\
(292 \text { had } \\
\text { endoscopic } \\
\text { surgery and } \\
648 \text { had } \\
\text { microscopic } \\
\text { surgery) }\end{array}$ & $\begin{array}{l}\text { Transient DI higher in the endoscopic group }(6.3 \%) \text { versus the microscope }(5.0 \%) \text {. No cases of } \\
\text { permanent DI in the endoscopic group, while } 2.8 \% \text { of patients in the microscopic group had permanent } \\
\text { DI. Higher rates of postoperative pituitary insufficiency in the endoscopic group }(7.9 \%) \text { versus } \\
\text { microscopic group ( } 5.2 \%) \text { Higher rates of cranial nerve palsy in endoscopic surgery }(1.4 \%) \text { than in } \\
\text { microscopic surgery }(0.8 \%) \text {. Higher rates of CSF leaks in the endoscopic group }(4.4 \%) \text { versus in the } \\
\text { microscopic group }(2.1 \%) \text {. No mortality in the endoscopic group whereas } 7 \text { people died in microscopic } \\
\text { with a pooled proportion of } 1.5 \% \text {. }\end{array}$ \\
\hline $\begin{array}{l}\text { Broerson } \\
\text { et al, } 2018 \\
\text { [13]. }\end{array}$ & $\begin{array}{l}97 \text { studies } \\
6695 \text { patients } \\
(984 \text { had } \\
\text { endoscopic } \\
\text { surgery and } \\
5711 \text { had } \\
\text { microscopic } \\
\text { surgery) }\end{array}$ & $\begin{array}{l}\text { Similar remission rates }(80 \%) \text { for both techniques. Hydrocortisone dependency was seen in } 39.3 \% \\
\text { patients in microscopic surgery and } 33.5 \% \text { after endoscopic surgery. Similar recurrence rates (10\%) for } \\
\text { both techniques. Fewer rates of CSF leaks with microscopic surgery (4.0\%) than in endoscopic surgery } \\
\text { (12.9\%). SIADH, bleeding and permanent DI were seen slightly less often in patients after microscopic } \\
\text { surgery, than in patients after endoscopic surgery. Transient DI was reported more often in patients } \\
\text { after microscopic surgery }(21.7 \%) \text { than in endoscopic surgery }(11.3 \%) \text {. Recurrence rates } 17.0 \% \text { after } \\
\text { microsurgery and } 1.5 \% \text { after endoscopic surgery. }\end{array}$ \\
\hline $\begin{array}{l}\text { N Qiao, } \\
2018 \text { [30]. }\end{array}$ & $\begin{array}{l}24 \text { studies } \\
1670 \text { patients } \\
\text { (702 patients } \\
\text { had } \\
\text { endoscopic } \\
\text { surgery and } \\
968 \\
\text { microscopic } \\
\text { surgery) }\end{array}$ & $\begin{array}{l}\text { No significant difference in remission rates between endoscopic surgery }(79.7 \%) \text { and microscopic } \\
\text { surgery }(76.9 \%) \text {. Recurrence rates for endoscopic surgery were } 11.0 \% \text { and for microsurgery, } 15.9 \% \\
\text { Proportion of remission in micro-adenomas was statistically significantly higher in the endoscopic } \\
\text { group }(87.3 \%) \text { than in the microscopic group }(79.3 \%) \text {. }\end{array}$ \\
\hline
\end{tabular}

TABLE 2: Summary of systemic reviews and metanalysis published on endoscopic versus microscopic transsphenoidal resection of Pituitary adenomas that were available on PUBMED as full-text articles

Abbreviations: DI: Diabetes Insipidus, CSF: cerebrospinal fluid, SIADH: syndrome of inappropriate antidiuretic hormone 


\section{Conclusions}

According to the literature published to date, an endoscope is an effective tool in transsphenoidal surgeries. Its superior view along with better patient prognostics establish it as a superior modality for Cushing's disease when compared with the microscope. Significant limitations need to be considered, however, as there exists a learning curve for surgeons using the endoscope. Lack of maneuverability and extra-cranial complications need to be addressed as well. In the future, 3D endoscopes may perhaps become a mainstream modality. The operative microscope can till then be utilized upon the surgeon's discretion.

\section{Additional Information \\ Disclosures}

Conflicts of interest: In compliance with the ICMJE uniform disclosure form, all authors declare the following: Payment/services info: All authors have declared that no financial support was received from any organization for the submitted work. Financial relationships: All authors have declared that they have no financial relationships at present or within the previous three years with any organizations that might have an interest in the submitted work. Other relationships: All authors have declared that there are no other relationships or activities that could appear to have influenced the submitted work.

\section{References}

1. Cushing H: The basophil adenomas of the pituitary body and their clinical manifestations (pituitary basophilism). Obes Res. 1994, 2:486-508. 10.1002/j.1550-8528.1994.tb00097.x

2. Cebula H, Baussart B, Villa C, et al.: Efficacy of endoscopic endonasal transsphenoidal surgery for Cushing's disease in 230 patients with positive and negative MRI. Acta Neurochir. 2017, 159:1227-1236. 10.1007/s00701-017-3140-1

3. Rutkowski M, Flanigan P, Aghi M: Update on the management of recurrent Cushing's disease . Neurosurg Focus. 2015, 38:E16. 10.3171/2014.11.FOCUS14703

4. Seltzer J, Lucas J, Commins D, Lerner O, Lerner A, Carmichael J, Zada G: Ectopic ACTH-secreting pituitary adenoma of the sphenoid sinus: case report of endoscopic endonasal resection and systematic review of the literature. Neurosurg Focus. 2015, 38:E10. 10.3171/2014.10.FOCUS14685

5. Pivonello R, De Martino M, De Leo M, Simeoli C, Colao A: Cushing’s disease: the burden of illness . Endocrine. 2017, 56:10-18. 10.1007/s12020-016-0984-8

6. Sheth S, Bourne S, Tritos N, Swearingen B: Neurosurgical treatment of Cushing disease . Neurosurg Clin N Am. 2012, 23:639-651. 10.1016/j.nec.2012.06.006

7. Netea-Maier R, van Lindert E, den Heijer M, et al.: Transsphenoidal pituitary surgery via the endoscopic technique: results in 35 consecutive patients with Cushing's disease. Eur J Endocrinol. 2006, 154:675-684. 10.1530/eje.1.02133

8. Berker M, Işikay I, Berker D, Bayraktar M, Gürlek A: Early promising results for the endoscopic surgical treatment of Cushing's disease. Neurosurg Rev. 2013, 37:105-114. 10.1007/s10143-013-0506-6

9. Donofrio C, Losa M, Gemma M, Giudice L, Barzaghi L, Mortini P: Safety of transsphenoidal microsurgical approach in patients with an ACTH-secreting pituitary adenoma. Endocrine. 2016, 58:303-311. 10.1007/s12020-016-1214-0

10. van Haalen F, Broersen L, Jorgensen J, Pereira A, Dekkers O: Management of endocrine disease: mortality remains increased in Cushing's disease despite biochemical remission: a systematic review and metaanalysis.. Eur J Endocrinol. 2015, 172:143-149. 10.1530/EJE-14-0556

11. Hassan-Smith Z, Sherlock M, Reulen R, et al.: Outcome of Cushing's disease following transsphenoidal surgery in a single center over 20 years. J Clin Endocrinol Metab. 2012, 97:1194-1201. 10.1210/jc.2011-2957

12. Zhuang Z, Liu X, Bao X, et al.: Invasive ACTH-secreting pituitary macroadenoma in remission after transsphenoidal resection. Medicine. 2018, 97:e13148. 10.1097/MD.0000000000013148

13. Broersen L, Biermasz N, van F, de V, Verstegen M, Dekkers O, Pereira A: Endoscopic vs microscopic transsphenoidal surgery for Cushing's disease: a systematic review and meta-analysis. Pituitary. 2018, 21:524-534. 10.1007/s11102-018-0893-3

14. Honegger J, Grimm F: The experience with transsphenoidal surgery and its importance to outcomes . Pituitary. 2018, 21:545-555. 10.1007/s11102-018-0904-4

15. Goudakos J, Markou K, Georgalas C: Endoscopic versus microscopic trans-sphenoidal pituitary surgery: a systematic review and meta-analysis. Clin Otolaryngol. 2011, 36:212-220. 10.1111/j.1749-4486.2011.02331.x

16. Dallapiazza R, Oldfield E, Jane J: Surgical management of Cushing's disease. Pituitary. 2015, 18:211-216. 10.1007/s11102-015-0646-5

17. Storr H, Drake W, Evanson J, et al.: Endonasal endoscopic transsphenoidal pituitary surgery: early experience and outcome in paediatric Cushing's disease. Clin Endocrinol. 2013, 80:270-276. 10.1111/cen.12275

18. Sarkar S, Rajaratnam S, Chacko G, Mani S, Hesargatta A, Chacko A: Pure endoscopic transsphenoidal surgery for functional pituitary adenomas: outcomes with Cushing’s disease. Acta Neurochir. 2016, 158:7786. 10.1007/s00701-015-2638-7

19. Reppucci M, Dehdashti A: Endoscopic endonasal resection of ACTH secreting pituitary microadenoma; how I do it. Acta Neurochir. 2016, 158:1617-1620. 10.1007/s00701-016-2846-9

20. Ammirati M, Wei L, Ciric I: Short-term outcome of endoscopic versus microscopic pituitary adenoma surgery: a systematic review and meta-analysis. J Neurol Neurosurg Psychiatry. 2012, 84:843-849. 10.1136/jnnp-2012-303194

21. Dehdashti A, Gentili F: Current state of the art in the diagnosis and surgical treatment of Cushing disease: early experience with a purely endoscopic endonasal technique. Neurosurg Focus. 2007, 23:1-8. 
10.3171/foc.2007.23.3.11

22. Esquenazi Y, Essayed W, Singh H, Mauer E, Ahmed M, Christos P, Schwartz T: Endoscopic endonasal versus microscopic transsphenoidal surgery for recurrent and/or residual pituitary adenomas. World Neurosurg. 2017, 101:186-195. 10.1016/j.wneu.2017.01.110

23. Höybye C, GrenbäcK E, Thorén M, Hulting A, Lundblad L, von Holst H, Anggard A: Transsphenoidal surgery in Cushing disease: 10 years of experience in 34 consecutive cases. J Neurosurg. 2004, 100:634-638. 10.3171/jns.2004.100.4.0634

24. Jho H, Carrau R: Endoscopic endonasal transsphenoidal surgery: experience with 50 patients . J Neurosurg. 1997, 4:44-51. 10.3171/jns.1997.87.1.0044

25. Koutourousiou M, Winstead W: Endoscopic endonasal surgery for remission of Cushing disease caused by ectopic intracavernous macroadenoma: case report and literature review. World Neurosurg. 2017, 98:870.e5-870.e10. 10.1016/j.wneu.2016.12.021

26. Kuo C, Yen Y, Wu J, Chen Y, Huang W, Cheng H: Primary endoscopic transnasal transsphenoidal surgery for magnetic resonance image-positive Cushing disease: outcomes of a series over 14 years. World Neurosurg. 2015, 84:772-779. 10.1016/j.wneu.2015.04.059

27. Buchfelder M, Schlaffer S: Pituitary surgery for Cushing’s disease. Neuroendocrinology. 2010, 92:102-106. $10.1159 / 000314223$

28. Rotenberg B, Tam S, Ryu W, Duggal N: Microscopic versus endoscopic pituitary surgery: A systematic review.. Laryngoscope. 2010, 120:1292-1297. 10.1002/lary.20949

29. Wagenmakers M, Boogaarts H, Roerink S, et al.: Endoscopic transsphenoidal pituitary surgery: a good and safe primary treatment option for Cushing's disease, even in case of macroadenomas or invasive adenomas. Eur J Endocrinol. 2013, 169:329-337. 10.1530/EJE-13-0325

30. Qiao N: Outcome of endoscopic vs microsurgical transsphenoidal resection for Cushing's disease . Endocr Connect. 2018, 7:R26-R27. 10.1530/EC-17-0312

31. Rolston J, Han S, Aghi M: Nationwide shift from microscopic to endoscopic transsphenoidal pituitary surgery. Pituitary. 2016, 19:248-250. 10.1007/s11102-015-0685-y

32. Smith T, Hulou M, Huang K, Nery B, de Moura S, Cote D, Laws E: Complications after transsphenoidal surgery for patients with Cushing's disease and silent corticotroph adenomas. Neurosurg Focus. 2015, 38:E12. 10.3171/2014.10.FOCUS14705

33. Pu J, Wan Z, Zhou H, Zhong A, Jin K, Ruan L, Yang G: Isolated double adrenocorticotropic hormonesecreting pituitary adenomas: a case report and review of the literature. Oncol Lett. 2016, 12:585-590. 10.3892/01.2016.4673

34. Starke R, Reames D, Chen C, Laws E, Jane J: Endoscopic transsphenoidal surgery for cushing disease: techniques, outcomes, and predictors of remission.. Neurosurgery. 2013, 72:240-247. 10.1227/NEU.0b013e31827b966a

35. Teo C, Wait S: Endonasal approach to tumors of the pituitary fossa: a shift in the treatment paradigm . Clin Neurosurg. 2011, 58:79-83. 10.1227/NEU.0b013e318226a25c

36. Yano S, Kawano T, Kudo M, et al.: Endoscopic endonasal transsphenoidal approach through the bilateral nostrils for pituitary adenomas. Neurol Med Chir. 2009, 49:1-7. 10.2176/nmc.49.1 